Милош М. Ковачевић

Универзитета у Београду

Филозофски факултет

Универзитета у Источном Сарајеву

\title{
У ЗАШТИТУ СРПСКОГ ЈЕЗИКА И ЋИРИЛИЦЕ
}

Одавно је констатовано, уз изношење низа неспорних аргумената, да су и српски језик и ћирилица врло угрожени, и то не од јуче. Они су толико угрожени у појединим аспектима да се може чак говорити о алармантном стању, које тражи неодложне и ефикасне мјере заштите. А међу тим мјерама чини се да су најбитније ${ }^{1}$ : a) вратити општекултурни и општеобразовни дигнитет српском језику и ћирилици преко школског система, прије свега преко друкчијег статуса у средњошколском и високошколском образовању; б) вратити научни дигнитет српском језику и ћирилици, прије свега кроз обезбјеђење друкчијег институционалног (политичког) односа према српском језику и ћирилици (институт за српски језик у Српској, савјет за српски језик, различити типови уџбеника и приручника, научни пројекти и сл.); в) научно штитити лингвистички идентитат српског језика у односу на политички идентитет његових варијаната; г) обезбиједити јединственост српског културног и језичког простора, и д) васпоставити темељне поставке српског филолошког програма, као нужне смјернице дјеловања српске филолошке науке и српске политике у оквиру хармонизованог «наступања» лингвиста и поли-

1 Овај рад представља синтезу ауторових ставова и идеја презентованих и шире научно елеборираних у низу радова, а пре свега у књигама: Ковачевић 2013, 2015, и 2017. 
тичара у провођењу научно засноване и национално пробитачне српске језичке политике.

Кључне ријечи: српски језик, ћирилица, варијанте српског језика, англицизација, језичка политика

Данашњи српски књижевни или стандардни језик у оквиру словенских и индоевропских језика уникатан је у низу фонолошко-прозодијских особина. Он тако, на примјер, једини има (u)јекавску замјену прасловенског гласа „јат“, једини има слоготворно р, једини има гласове $\hbar$ и $\hbar$, једини има промјену л у о на крају ријечи или слога, једини има два узлазна и два силазна акцента (уп. Маројевић 2000:15-16). Његова специфичност не потврђује се само наведеним фонолошко-прозодијским карактеристикама него, и још више, социолингвистичким карактеристикама. Међу свим језицима у свијету он сигурно нема премаца по броју различитих (пре)именовања. При том је српски језик био и остао основни идентитетски критеријум српскога народа. Наиме, српски народ с највећим бројем европских народа дијели заједничку карактеристику да му је језик темељни идентитетски критеријум. Српска интелектуална елита од самих је почетака «сагледавала нацију као 'заједницу језика', где је језик представљао чинилац обједињавања и повезивања свих припадника друштва. Концепт лингвистичког типа нације био је присутан већ у просветитељском раду Доситеја Обрадовића, где је на тај начин одређена српска нација», с тим да је «дефинитивно обележје нације као 'заједнице језика' - и то у духу немачког романтизма - утемељио истраживачки лингвистичко-етнографски рад Вука Караџића» (Пишев 2013:28-29). Тако је, прије свега Вуковом заслугом, српски језик (п)остао најсуштаственија диференцијална црта Срба према другим словенским и несловенским народима. Послије Вукове смрти, међутим, 
најприје у заносу југословенства, а потом на таласу братства и јединства, српски књижевни језик добио је, на Новосадском договору (1954) уз српски пристанак, сложеничко

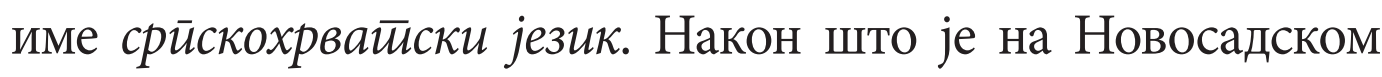
договору и званично српско име Вуков(ск)ог књижевног језика замијењено српскохрватским, сва даља дешавања била су усмјерена ка томе да се заборави на исходиште српскохрватског у српском, и да се намјесто српског устоличи српскохрватски као исходиште. У периоду од Новосадског договора до посљедње деценије ХХ вијека Хрватима је основни циљ био да пронађу «подлогу» за хрватски удио што га је подразумијевао сложенички назив српскога језика: српскохрватски језик.

А тај тренутак наступио је у посљедњој деценији XX вијека. Измијењене друштвено-политичке прилике још једном су форми дале примат над суштином. Баш као што је стварање заједничке државе погодовало дометању и од српске стране прихватању хрватског имена у називу српскога језика, управо тако је и распад заједничке државе (СФРЈ) погодовао осамостаљењу тог дометнутог имена. Јер, ако се «сложена» држава распада, зар није логично да се и њен «сложени језик» (а његову сложеност тобож најбоље потврђује управо сложенички назив његов) распадне?!

За Хрватима су се повели и муслимани (који су у вријеме грађанског рата себе чак национално преименовали у Бошњаке) издвајајући из српскохрватског језика свој «босански језик», правдајући то «неотуђивим правом свакога народа да свој језик назива властитим именом», правом које су измислили Хрвати 1967. године у познатој Деклараиији о називу и йоложсају хрвайской кюижевноі језика. (Ковачевић 2012, и Ковачевић 2013:13-29). То псеудоправо што га измислише хрватски филолози 1967. године, филолози из реда других балканских народа - на жалост и српски (о чему в. у: Ковачевић 2015:194) - или зато што нису провјеравали његову правну утемељеност или зато што им је оно одго- 
варало за оправдавање властитих на науци и праву неутемељених поступака - прихватали су и ширили, тако да је оно код појединих лингвиста оквалификовано као «обичајно право», односно «југословенска традиција». За Хрватима и Муслиманима кренуше и Црногорци, објеручке прихвативши измишљено хрватско «право», па га чак везаше и за «међународне документе», не упућујући нормално ни на какве изворе (а и како ће, кад они једноставно не постоје!), тврдећи да «међународни документи гарантују право на сопствени језик, тако да и ови документи иду у прилог политичким разлозима за увођење назива црногорски језик» (Лакић 2013: 140). И српски језик под српскохрватским именом - умножи се дијељењем, добивши чак три несропска имена: хрватиски, босански и ирноїорски језик.

Сви ти «језици» као да призивају социолошки појам ирройонација, јер «оне готово увек имају политичке вође које тврде да дотична група има право на сопствену националну државу и да њом не треба да 'владају други'» (Ериксон 2004:34-35). Добивши сањану државу, политичке елите, или чак «вође», у државицама насталим распадом СФРЈ као да своје дјеловање изводе из оних социолошких теорија национализма по којима се национализам «експлицитно или имплицитно позива на неку нарочиту везу између етницитета и државе. Сходно томе, национализам би био етничка идеологија према којој одређена група треба да доминира у држави. Онда је национална држава у којој превласт има једна етничка група, а основна обележја њеног идентитета (попут језика или религије) често су и интегрисана у званичну симболику и законодавство» (Ериксон 2004: 172-173), при чему неријетко те владајуће елите прибјегавају «свјесном конструисању етничког идентитета» преко манипулације «историјом и културним симболима» (Ериксон 2004: 124).

За Србе, и оне у Српској и оне у Србији, ако се у обзир узме само преименовање српскога језика, најо- 
паснији је «бошњачки национализам» коме је «босански језик» упоришни критеријум. На дјелу је заправо «повампирена Калајева језичка и национална политика у БиХ» (Ковачевић 2015: 137-144) која преко «земаљског језика» жели да створи босанску нацију, коју би чинили сви становници БиХ (па чак и Рашке, односно Санџака, како Рашку Бошњаци именују), а чији би основни интегришући конституент био управо «босански језик».

Осим социолингвистичких питања, везаних прије свега за преименовања српскога језика, данашњицу српскога језика оптерећују и питања алоглотских утицаја што угрожавају његову структуру. Наиме, данашњи српски језик, посматран и у цјелини и као систем варијаната, изложен је веома јакој анілицизацији. «У протеклих десетак година, код нас (али не само код нас) догодила се права експлозија језичке англоманије. Она сада прелази у свој екстремни стадијум - језички аніллохолизам, који се може описати као опијеност неконтролисаним уношењем свакојаких елемената и појава из енглеског језика у српски» (Прћић 2005:183). «Крајњи резултат овакве културне и образовне климе огледа се у све већем продору енглеског језика у српски и у све упадљивијој хибридизацији српског језика, односно у настанку нечега што се може назвати англосрпским језиком: то је један нови урбани социолект, првобитно својствен људима млађе генерације, који представља врсту српског језика који (све више) одступа од својих норми и (све више) бива употребљаван према нормама енглеског језика» (Прћић 2005:185). Англицизација српског језика «се већ сада јасно уочава на плану речи, структура/образаца, значења и употреба» (Прћић 2005:185). Тако она, на примјер, «у популарној женској периодици упечатљиво, незаустављиво и стихијски разара структура српског језика» (Јањић, Чутура 2012:94). Данас англицизација пријети (у)ништењу темељних вриједности српскога 
језика. Актуелна истраживања, наиме, показују «да је речник средњошколаца пун нових англицизама, али да њихова рецепција најчешће не одговара семантичким еквивалентима у енглеском језику. Присуство неадаптираних англицизама у говору младих (и не само њих) део је процеса спонтане акултурације, који се интензивно намеће као доминантан друштвени контекст у условима светске глобализације. Сасвим је извесно да ток овог процеса неумитно води ка стварању језичке хибридизације, која се за сада испољава у виду такозваних србоанглицизама, односно англосрбизама, тј. неадаптираних сирових англицизама» (Јањић, Чутура 2012:79). А посљедица тога је - што је најгоре - да се «највећа национална вредност, еманација духа народа - његов књижевни језик - не препознаје као пожељни систем комуникације међу младима» (Јањић, Чутура 2012:64).

Зато мора чуђење да изазове чињеница да се данас у српским медијима све чешће наилази на ставове које пропагирају не само лингвистички лаици него чак и, истина ријетки, лингвисти универзитетски професори - о непотребности бриге за очување књижевног или стандардног српског језика, па чак и непотребности његових норми уопште. Често се, наиме, може чути и прочитати, а најчешће од површно упућених у суштину међуодноса језика и стандардног језика да је «правилно све што постоји у језику. Ниједан говор, ниједан идиолект, није неисправан». Има чак и лингвиста који, сводећи све језичке функције на комуникативну, испољавајући игнорантски однос према норми, не разликујући језички од стандарднојезичког узуса, не могу да схвате нити прихвате» (Арсенијевић 2013). Не уважава се, дакле, чињеница да је нужно разликовати језичку норму од норме стандардног језика. А самим тим и (не)правилност у оквиру језика од (не)правилности у оквиру стандардног или књижевног језика. Зато када се говори 
о нарушавању језичке норме, «о језичкој норми се не говори као о језичком узусу, који је присутан у сваком језику и дијалекту независно од степена њихове књижевнојезичке развијености, него као о коgификованом узусу, односно као о оним особинама неког језика које меродавне институције или појединци предлажу као прописани, односно друштвено прихватљиви облик понашања на том језику» (Пипер, Клајн 2013: 5).

У супротном, уколико бисмо изједначили кодификовани са језичким узусом, готово да бисмо морали препоручити спонтано прилагођавање говорниковог комуникацијског понашања језичком узусу средине, што као резултат по правилу даје оно што је Т. Прћић назвао «немарним функционалним стилом». А то је «убедљиво најзаступљенији језички варијетет у нашој јавној употреби, пре свега у многим штампаним и електронским медијима, и у говору и у писању, а затим и свугде где се говори и пише (а потом и језички мисли?) под њиховим утицајем - у спонтаном говору, у комуникацији путем интернета, на уличним натписима, на рекламним паноима. [....] Настанак немарног ‘функционалног стила' последица је понашања по коме се језик схвата као пука комуникациона алатка, чија се једина функција састоји у каквом-таквом преношењу поруке, док се одабиру и начину употребе језичких средстава поклања мало или, чешће, нимало пажње» (Прћић 2005: 22). Основно својство немарног «функционалног стила» јесте «непознавање, непоштовање и незаинтересованост за постојећу норму српског језика, али и одсуство свести о постојању такве норме, при чему се говори и пише ослањањем на сопствено језичко осећање, мишљење или веровање, без посезања за језичким и другим приручницима. Стога се овакви корисници језика, уз извесну дозу сарказма и поспрдности, могу назвати 'осећајним' корисницима језика, чије језичко понашање (као да) опредељује наслов једне Шекспирова комедије - 'Како вам драго'» (Прћић 2005: 22-23). 
Заговорници игнорисања норме, а у њих треба убројати како оне који сматрају да је «у језику све исправно» тако и оне што тврде да је «језичко понашање у типичном случају нетранспарентно, као што је то и ходање» - заправо су заговорници и бранитељи немарног «функционалног стила» у српском стандардном језику. А данашње стање српске језичке културе најближе је управо овако схваћеном немарном «функционалном стилу». Разлог томе свакако треба тражити у статусу самог српског књижевног језика у школскоме системе, а посебно на универзитету. Наиме, код Срба се прије не подразумијева него што се подразумијева да су факултетски образовани појединци функционално писмени. Не може се, наиме, бити функционално писмен уколико се не познаје елементарна писменост, уколико појединац нема ни елементарна нормативна знања стандардног српског језика. А и не може их имати ако се са учењем српског језика једини и посљедњи пут у току свог школовања сусреће у основној школи.

Уз преименовање и доминацију «немарног функционалног стила» данашњицу српскога језика карактерише и одумирање ћирилице као српског националног писма. Сигурно је, наиме, «да никада ниједно писмо - сем српске ћирилице - није ниподаштавано од властитог народа, или боље речено: од оних који тај народ (желе да) представљају. А српска ћирилица је, што је општепознато, најсавршеније писмо на свијету, јер у њој свакоме књижевном гласу (фонеми) српскога језика одговара посебно слово (графема). То писмо у облику који оно данас има Србима је подарио Вук Стефановић Караџић. Многе Вукове завјете Срби су заборављали и заборавили у ових сто педесет година од његове смрти. А посебно су ћирилицу почели да 'избјегавају' и заборављају. Иако је ћирилица једино српско национално писмо, иако она Србе прати од почетака писмености до 
данас, у посљедњем стољећу она код Срба бива све више потискивана латиницом, и све чешће њом замјењивана. А латиницу је највећи број Срба добио тек почетком двадесетог вијека. Она је дошла заједно са уласком Хрвата у заједнички државу - најприје Краљевину Срба, Хрвата и Словенаца, а онда и Југославију» (Ковачевић 2015:97). За сто година ћирилица и латиница употребно су код Срба потпуно замијениле мјеста. Латиница је код Срба стално потискивала ћирилицу док је није довела до самог затирања, одумирања.

Тако су све три суштинске карактеристике српскога књижевног (стандардног) језика данас «у проблему», да не кажемо «у кризи»: а) српско име као одраз његове етнолингвистичке суштине, б) ћирилица као идентитетска карактеристика српског народа, и в) алоглотско нарушавање структуре српскога језика.

Зато је пред српском филологијом много неодложних, али и дугорочних задатака, од којих наводимо само оне најзначајније а неодложне.

1) Будући да српски језик у односу на своје варијанте има хиперонимски статус, српска филологија на њ мора примјењивати критеријуме који важе за све полицентричне свјетске језике - језике који су варијантно раслојени, којим се користи више народа, али која према свим лингвистичким идентитетским критеријумима представљају један језик, какви су нпр. енглески, њемачки, шпански, португалски. Што се пак тиче његових кохипонима - хрватског, босанског/бошњачког, и црногорског - јасно је да ће српска филологија увијек истицати да су у питању само различити стандарди, односно различите варијанте Вуков(ск)ог српског књижевног језика. Српска филологија при образлагању лингвистичког статуса тих назовијезика, примјењујући на њих међународне правне и научне критеријуме, а посебно критеријуме идентификације мањинских језика што их је понудила Евройска 
йовета о реіионалним или манинским језицима (Закон 2005), у којој се у њеном члану 1 , именованом као „Дефиниција“, што је сав посвећен одређењу идентификације регионалних или мањинских језика, каже:

„За потребе ове повеље:

a) „регионални или мањински језици“ су језици који:

(I) су традиционално у употреби на одређеној територији једне државе од стране држављана те државе који чине бројчано мању групу од остатка становништва те државе и који су

(II) различитии о званичної језика йе gржаве,

што не укључује дијалекте званичног језика те државе или језике радника миграната“. (Закон 2005: 1-2)

Из наведене се повеље имплицитно нужно закључује gа gва или више ияиома који се не разликују не моіу линівисииччки (научно) бийи йосебни језици. Зато је неопходно да у српским законима о језику буде строго диференцирана функција како лингвистичких и политичких језика, тако и комуникативних и симболичких мањинских језика.

2) Неопходно је вратити општекултурни и општеобразовни дигнитет српском језику и ћирилици преко школског система, прије свега преко друкчијег статуса у средњошколском и високошколском образовању. А то је

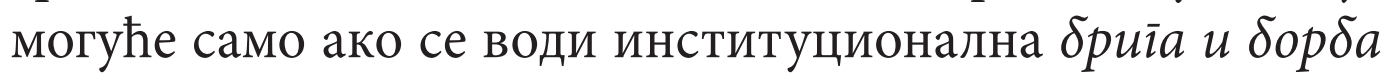
за кулитуру срйскоїа језика. Никада као данас није било више језичке некултуре. Статус српског језика и језичке културе не може се побољшати ако се не промијени његов статус у цијелом образовном систему. Српскога језика, наиме, готово да ни по изузетку нема ни на једном од ненаставничких нефилолошких факултета. А не би, ни у Србији ни у Српској, смио постојати ниједан факултетски тип школовања а да не подразумева елементарну и функционалну писменост. Зато је неопходно, уз учешће свих научних, језичких, педагошких и културних установа, израдити национални концепт изучавања 
српскога језика, који ће српскоме језику вратити дигнитет, а Србима више него елементарну писменост.

Треба подсјетити да на свим факултетима српски језик има статус вехикуларног језика, тј. језика на којем се изводи настава. И само из тих разлога било би неопходно да сваки како професор тако и студент влада основама језичке културе, тј. правилне (и) контекстуално примјерене употребе српског стандардног језика. У језичке садржаје на ненаставничким факултетима нужно би било укључити садржаје језика струке (специфичне за сваку универзитетску дисциплину, на примјер за право, медицину, машинство, економију и сл.). Тако би у оквиру било ког универзитетског усмјерења садржаји српског језика морали бити заступљени бар на нивоу функционалне писмености. Иначе, како да се научно комуницира на српском језику, ако се не знају специфичне карактеристике српског језика при његовој реализацији у различитим научним стиловима, подстиловима или жанровима!? Зато је неопходно да сви факултетски смјерови, без обзира да ли су у питању наставнички или ненаставнички факултети били они државни или приватни - уведу српски језик.

3) Неопходно је вратити научни дигнитет српском језику и ћирилици, прије свега кроз обезбјеђење друкчијег институционалног (политичког) односа према српском језику и ћирилици. Та институционална небрига за српски језик и ћирилицу посебно је изражена у Републици Српској. Она се прије свега односи на нехајан однос главних институција које би морале да се баве заштитом српског језика и ћирилице, а то су Народна скупштина Републике Српске и Академија наука и умјетности Републике Српске.

Непојмљиво је да Скупштина није реаговала чак ни на покушај националног брисања српског народа, преко «асимилације» српског језика у «босански», у одлукама Уставног суда БиХ. Зачуђујуће је да то није била ниједном 
тема не само Народне скупштине РС него чак ниједне од 16 сједница скупштинског Одбора за образовање, науку, културу и информисање, одржаних у периоду од 2014. до краја 2016. Подсјетимо се, Уставни суд Босне и Херцеговине на пленарној сједници, одржаној 26. маја 2016. године закључио да је прва реченица члана 7. став 1. Устава Републике Српске у дијелу: «Језик бошњачког народа», неутрална одредба која не одређује назив језика, већ садржи уставно право конститутивног бошњачког народа да, као и сви конститутивни народи и остали који се тако не изјашњавају, језик којим говоре назову именом којим желе, што је у складу с Усйавом БиХ и свако супротно поступање у пракси водило би кршењу Устиава БиХ, али и Устилва РC. А Уставни суд Босне и Херцеговине такав став је донио одлучујући о захтјеву Сафета Софтића, другог замјеника предсједавајућег Дома народа БиХ, за оцјену уставности прве реченице члана 7. став 1. Устава РС у дијелу који гласи: «језик бошњачког народа».

Не само да Скупштина РС није разматрала наведену политикантску одлуку Уставног суда БиХ, него то није урадила ни Академија наука и умјетности Републике Српске. Међутим, као да АНУРС већ својим статутом «пере руке» од проблема српскога језика и писма у БиХ и

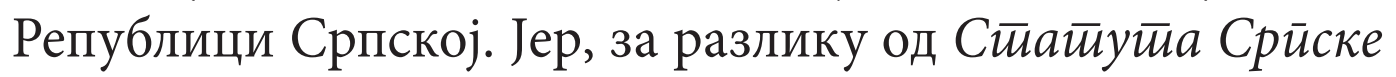

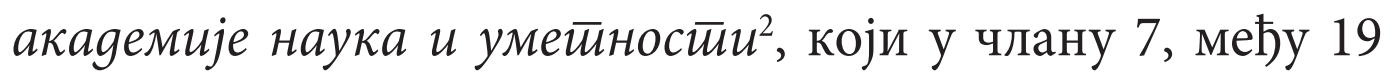
тачака којима се описује предмет њенога рада, у трећој тачки наводи да «води бригу о српском језику и ћири-

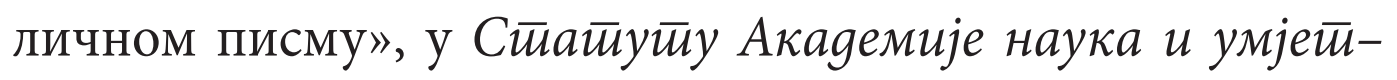

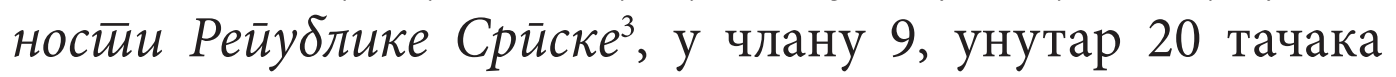
којима се описују задаци и премет рада АНУРС, преписано је 18 тачака из члана 7 САНУ, али је, што је врло симптоматично, изостављена тачка о српском језику и писму.

2 https://www.sanu.ac.rs/Novosti/STATUT-SANU

3 http://www.anurs.org/72/anurs/Statut/Akademije 
Тако је АНУРС, већ при изради свог статута, из дјелокруга свог рада искључила бригу о српском језику и ћириличном писму. Ако српски језик и писмо не улазе у дјелокруг рада АНУРС, ако Народна скупштина РС чак ни у раду свог Одбора за образовање, науку, културу и информисање не поклања пажњу српском језику и писму, ни у времену највећих бошњачких оспоравања српског језика у БиХ, и настојања да се он «укине» у тзв. босанском језику, поставља се питање да ли је најзначајнијим институцијама Републике Српске заиста, изузму ли се декларативне изјава појединаца, стало до институционалне одбране српског језика и ћирилице како у Републици Српској тако и у БиХ.

А да би актуелна непостојећа брига Народне скупштине и АНУРС о српском језику и ћирилици постала стварна брига и стално реализујући задатак, неопходно је да Народна скупштина формира посебан Одбор или Савјет за српски језик и писмо, а чини се још неопходније да донесе не само нови Закон о језику и йисму, него и да у Закону о високом образоваюу, који се управо налази у скупштинској процедури, због опште језичке некултуре, а ради стицања елементарне функционалне писмености уведе српски језик као обавезан предмет у цијелој универзитетској настави, тј. на свим факултетима.

Одбрана и заштита српског језика не може нити смије бити само декларативна. Она мора бити научно утемељена, и везана за научне институције и научне пројекте. А општепознато је да Република Српска нема института за српски језик и књижевност, и да је он неопходан из више разлога (које сам често образлагао, в. нпр.: Ковачевић 2015: 123-132). Прво, зато што српски језик нигдје није тако угрожен као у Босни и Херцеговини. Друго, што се болоњским процесима наука готово измјешта с факултета, што факултети постају мало јаче средње школе, у најбољем случају научно у рангу бивше 
више школе. Треће, што муслимани - који на све начине желе босански наметнути као земаљски језик, као језик и Срба и Хрвата и муслимана/ Бошњака - већ имају институт, који се све више представља као институт који изучава и покрива језичку проблематику цијеле Босне и Херцеговине. И на крају, мада не и посљедње, што је Република Српска, са источном Херцеговином као средиштем источнохерцеговачког дијалекта, који је основица цијелог Вуков(ск)ог српског књижевног језика, на неки начин предодређена да у њој буде институт за српски језик.

Институт за српски језик био би право мјесто за провођење и потврђивање општесрпске језичке политике, прво мјесто за општедруштвена лингвистичка истраживања, а самим тим и право мјесто за његовање и изучавање српскога језика и писма, а посебно и због тога што је Академија наука и умјетности Републике Српске из дјелокруга својих задатака и циљева искључила српски језик и књижевност. Зато је најприродније да институт, по угледу на Гетеов институт, или Сервантесов институт, буде везан за Андрићево име, да то буде Институт за српски језик и књижевност «Иво Андрић», у његовом граду - Андрићграду.

Научних истраживања нема без научних пројеката. А Република Српска, односно њено Министарство за науку као да су свјесно или намјерно укинули, да не кажемо забранили, пројекте који се баве аспектима српског језика и књижевности у Босни и Херцеговини. Зар томе најбоља потврда није резултат конкурса који је расписало Министарство науке Републике Српске крајем 2014. године, на коме сам као руководилац преко Филозофског факултета Пале пријавио наставак четворогодишњег пројекта, у чијој реализацији су учествовали истраживачи из Србије и Српске, а чији су резултати штампани у четири зборника насловљена самом темом пројекта: Значај срӣскої језика и книжевносӣи 


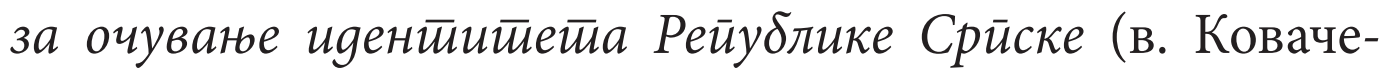
вић ред. 2012, 2013, 2014. и 2015). Сматрао сам, а и сада сматрам, да је то за Републику Српску један од најзначајнијих пројеката у времену када се води готово општенационална борба за очуваюе срйскої језика и ћирилице, и то како у Србији тако и у Републици Српској, у времену у коме се чак и судски процеси воде о статусу српскога језика у Републици Српској и Босни и Херцеговини, и у времену које сваки иоле озбиљан лингвиста карактерише као вријеме наглашено присутне језичке некулйуре. Уз то је изучавање српскога језика и књижевности као идентитетских критеријума Републике Српске и примарни национални циљ. Али тако није сматрало Министарство науке: оно једноставно није одобрило наставак финансирања тог пројекта, а да зло буде веће нити иједног другог пројекта који се тиче аспеката изучавања српског језика и књижевности у БиХ. Зато сматрам да је НУЖНО, због изузетног националног и научног значаја, одобрити не само наставак пројекта Значај срӣскоі језика и књи-

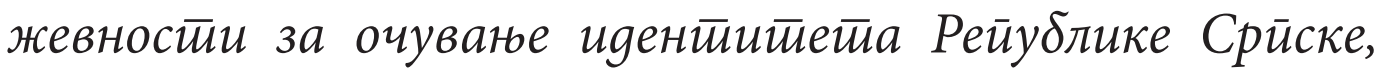
него и низ других пројеката са филолошком тематиком. Готово да је апсурдно да Министарство науке даје предност пројектима из нано технологије или пак из атомске физике, а одбија све пројекте из националне филологије. То је најбољи показатељ с каквом озбиљношћу Влада и њена министарства приступају очувању српског језика и ћирилице, а сљедствено и српског народа у Српској и БиХ, будући да су српски језик и ћирилица основни национални идентитетски критеријуми.

4) Српски филолози морају научно штитити лингвистички идентитат српског језика у односу на политички идентитет његових варијаната. То готово да захтијева недавна појава сарајевске Декларације о зајеgничком 
језику ${ }^{4}$ Основни циљ Декларације, како се то наводи и у Реаговању Одбора за језик СК $3^{5}$, садржан је у двјема тврдњама: 1) да су „све четири постојеће стандардне варијанте (српска, босанска, хрватска и црногорска) равноправне и не може се једна од њих сматрати језиком, а друге варијантама тог језика“, и 2) „чињеница да се ради о заједничком полицентричном језику оставља могућност сваком кориснику да га именује како жели“, што ће рећи да је и српско и хрватско, и босанско и црногорско именовање језика равноправно, и да треба да буде на цијелом простору „заједничког језика“ прихваћено. Та два става из Декларације директно негирају научне филолошке чињенице, а у корист српске штете.

Првом тврдњом српски језик се изједначава са својим варијантама. Јер су историјске и научне чињенице недвосмислене: хрватска, бошњачка и црногорска варијанта, које су политички проглашене језицима, јесу само варијанте СРПСКОГА ЈЕЗИКА. Зато је историјски и научно оправдан назив језика Срба срӣски језик, док

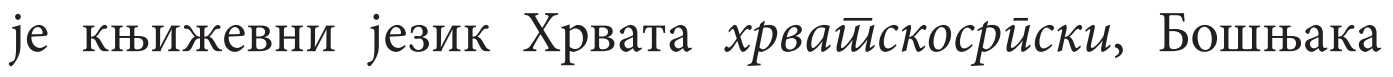

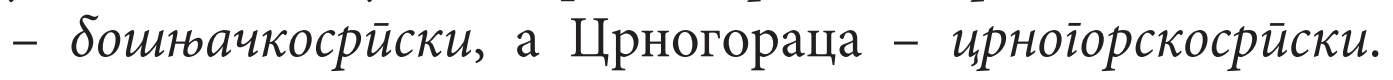
Српски језик једини има статус лингвистички утемељеног језика, док се његове варијанте политички језици, што ће рећи језици само по политички наметнутом несрпском имену. Зато аутори Декларације и заступају научно неутемељено становиште да свако може тај заједнички језик „да именује како жели“. А више је него знано шта за Србе значи, чак и кад је у питању симболичка функција језика, именовање српског језика „босанским“: значи нестанак и Срба и српског језика у Републици Српској, и њихово утапање у тзв. Босанце и босански језик. Сличан је слу-

4 Текст Deklaracije o zajedničkom jeziku доступан је на сајту: https://sh.wikipedia.org/wiki/Deklaracija_o_zajedničkom_jeziku.

5 Објављеном у часопису Нова Зора, бр. 53/54, Билећа-Гацко, 2017, 125-126. 
чај и са црногорским именом српског језика, чије признавање би значило укидање и Срба и српског језика у Црној Гори. Због тога наведена Декларација као основни циљ има „рјешавање“ српског националног и језичког питања у БиХ и Црној Гори, тако што ће се Срби превести у Босанце и Црногорце, а српски језик укинути у „босанском“ или „црногорском“, остављајући могућност да српски језик као варијанта обитава само у Србији. И да се све српско и у филологији сведе само на србијанско.

5) Морају се установити темељни критеријуми српског филолошког програма, као нужне смјернице дјеловања српске филолошке науке и српске политике у оквиру хармонизованог „наступања“ лингвиста и политичара у провођењу научно засноване и национално пробитачне српске језичке политике. А основно начело тог програма треба да буде јединствен српски језик за све Србе, или како је то Вук рекао: „Српских језика нема него један којим говори сав народ српски“. Том начелу комплементарно је и начело да су српска култура, књижевност и језик недјељиви и да обухватају сав српски народ. Основи српског филолошког програма треба да буду саставни и темељни дио Декларације о ойсйанку срйске нације и срӣскої нароgа, чију су израду најавили предсједници Србије и Републике Српске.

6) Први корак у очувању Срба и српског језика у Републици Српској и БиХ јесте заустиявљане йроцеса ояумирања ћирилице као битне идентитетске црте како српскога језика тако и српскога народа. Оно што обједињује српски народ, што му даје национални идентитет јесте - како се наводи и у Требиюској декларацији о

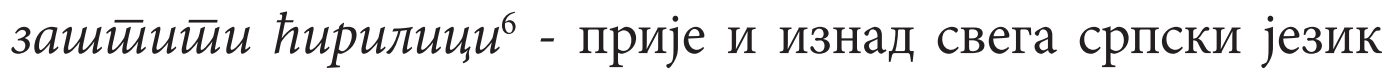
и његово писмо ћирилица. Српски језик и српска ћирилица темељни су идентитетски национални критеријуми

6 Објављеној у часопису Нова Зора, бр. 53/54, Билећа-Гацко, 2017, 135-138. 
српскога народа. Између српског језика и српске ћирилице влада однос какав неме ниједан други језик са својим писмом. Ћирилица је неотуђиви дио српскога језика, и зато је српски језик у свој пуноћи српски тек кад се исписује ћирилицом. Та два термина једино у српском језику, између свих језика на кугли земаљској, могу метонимијски да се замјењују: кад се каже српски језик нужно се мисли и на српску ћирилицу, а кад се каже српска ћирилица, то истовремено значи и српски језик. Српска ћирилица је, што је општепознато и научно општеприхваћено, најсавршеније писмо на свијету, јер у њој свакоме књижевном гласу (фонеми) српскога језика одговара посебно слово (графема). Ћирилица је данас толико потиснута латиницом да јој пријети потпуни нестанак.

Нужно је зато на свим просторима на којим Срби

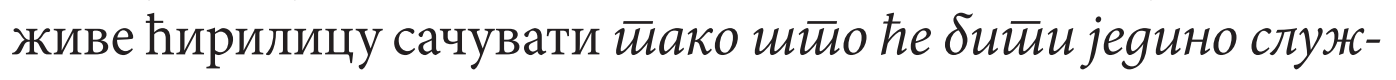
бено иичсмо иијелоїа срйскоїа нароgа. Обавезно је да се српска политичка и филолошка дјеловања нађу на истом путу, на путу заустављања ништења српског националног идентитета због неуважавања значаја српског језика и српске ћирилице као основних националних одредница. На том послу потребно је да се нађу све српске институције и сви српски филолози и утицајни политичари. У вези с тим, неопходно је што прије направити заједнички ћирилички буквар, екавског и ијекавског изговора, који ће бити и потврда почетка практичне реализације службеног статуса ћирилице код Срба без обзира на то гдје они живе.

Да закључимо. Све наведено показује да је прошло вријеме описа готово катастрофалног актуелног стања савременог српскога језика и ћирилице, и дошло вријеме конкретног дјеловања, које ће потпомоћи превазилажењу тог стања и враћању дигнитета српском језику и ћирилици и код самога српскога народа. А међу неодложним активностима које се морају подузети ради очувања српског језика и ћирилице посебно у Републици Српској, 
која је и најизложенија језичкој асимилацији, јесте оснивање Института за српски језик и књижевност. Институт за српски језик био би право мјесто за провођење и потврђивање општесрпске језичке политике, прво мјесто за општедруштвена лингвистичка истраживања, и мјесто реализације већег броја филолошких пројеката посвећених изучавању српског језика и књижевности не само у Републици Српској него и с обзиром на цјелину српског језичког простора. У времену опште језичке некултуре која је карактеристика и највећег броја факултетски образованих неопходно је да сви факултетски смјерови, без обзира да ли су у питању наставнички или ненаставнички факултети били они државни или приватни - уведу српски језик, како би бар они факултетски образовани били елементарно и функционално писмени.

\section{Литература:}

Арсенијевић 2013: Boban Arsenijević, Jezička kultura, <http:// inform-al.blogspot.com/2013/11/iz-jednog-clanka-unovostima-httpwww.html> (pristup: 17. 11. 2013).

Ериксон 2004: Tomas Hilan Erikson, Etnicitet i nacionalizam, s engleskog prevela Aleksandar Bajazetov-Vučen, Beograd: Biblioteka XX vek.

Закон 2005: «Закон о ратификацији Европске повеље о регионалним или мањинским језицима», Службени листи СЦГ - Међународни уіовори, бр. 18/2005 од 23.12.2005. године.

Јањић, Чутура 2012: Марина Јањић, Илијана Чутура, Простиор, време, gрушишво - сусретии у језику, Јагодина: Педагошку факултет у Јагодини.

Ковачевић 2012: Милош Ковачевић, «Постоји ли право народа на сопствено име именом туђег језика», у: Језик и иисмо y Рейублици Срйској, зборник радова, уредник Рајко Кузмановић, Бања Лука: АНУРС, Научни скупови, књ. XXIV, Одјељење књижевности и умјетности, књ. 13, 297-311. 
Ковачевић 2013: Милош Ковачевић, Линівистиика као србистиика, Монографије и монографске студије, књ. 1, Пале: Универзитет у Источном Сарајеву, Филозофски факултет. Ковачевић 2015: Милош Ковачевић, Срйски језик између линівистиике и йолитиике, Бања Лука: Друштво наставника српског језика и књижевности Републике Српске.

Ковачевић 2017: Милош Ковачевић, Срӣски језик йоg луйом науке, Београд: Завод за уџбенике.

Ковачевић ( ред.) 2012: Значај срӣскої језика и кюижевностии у очувағу ияентиитетей Рейублике Срйске II: Кюижевни класици Рейублике Срйске, зборник радова, уредник Милош Ковачевић, Пале: Филозофски факултет.

Ковачевић (ред.) 2013: Значај срӣскої језика и књижевностии у очувағу ияентичитетиа Рейублике Срйске II: Кюижевни класищи Рейублике Срйске: Кочић и Ћойић, зборник радова, уредник Милош Ковачевић, Пале: Филозофски факултет.

Ковачевић (ред.) 2014: Значај срӣскої језика и књижевностии у

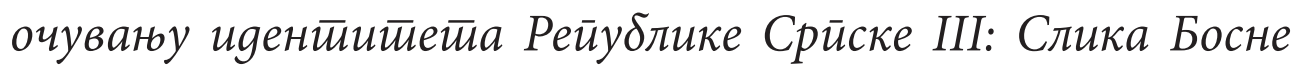
и Херцеіооине у дјелима савремених иисаца Рейублике Срйске, зборник радова, уредник Милош Ковачевић, Пале: Филозофски факултет.

Ковачевић (ред.) 2015: Значај срӣскоі̄ језика и књижевностии

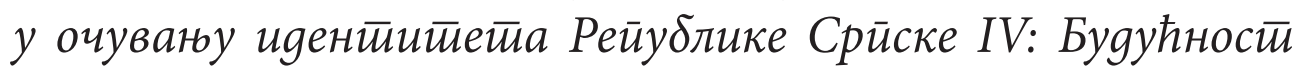
срйскоі̄ језика и књижевностии у Рейублици Срйској и йроцеси (gез)инӣеірација, зборник радова, уредник Милош Ковачевић, Пале: Филозофски факултет.

Лакић 2013: Igor Lakić, «Jezička slika Crne Gore», u: Jezik između lingvistike $i$ politike, Vesna Požgaj Hadži (ur.), Beograd: Biblioteka XX vek, 133-158.

Маројевић 2000: Радмило Маројевић, Срйски језик gанас, Београд: ЗИПС, Српска радикална странка.

Пипер, Клајн 2013: Предраг Пипер, Иван Клајн, Нормаичивна

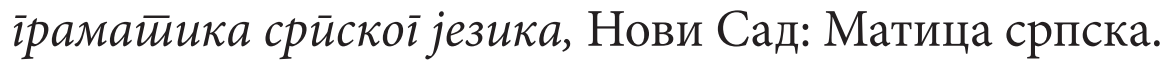

Пишев 2013: Marko Pišev, Politička etnografija i srpska intelektualna elita u vreme stvaranja Jugoslavije 1914-1919: Slučaj Jovana Cvijića, Beograd: Filozofski fakultet.

Прћић 2005: Tvrtko Prćić, Engleski u srpskom, Novi Sad: Zmaj. 
Miloš M. Kovačević

Faculty of Philosophy, University of East Sarajevo

Faculty of Philology, University of Belgrade

\section{IN PROTECTION OF THE SERBIAN LANGUAGE AND CYRILLIC ALPHABET}

\section{Summary}

It has long been established, with a series of indisputable arguments, that the Serbian language and Cyrillic alphabet are extremely endangered, and not since yesterday. They are so endangered in certain aspects that one can even speak of an alarming state, which requires immediate and effective protection measures. And among these measures it seems that the most important ones are the following : a) restore the overall cultural and educational dignity of the Serbian language and Cyrillic alphabet within the educational system, primarily through a different status in secondary and higher education; b) restore scientific dignity of the Serbian language and Cyrillic alphabet primarily through ensuring a different institutional (political) relationship towards the Serbian language and Cyrillic alphabet (Serbian Language Institute in Srpska, Serbian Language Council, various types of textbooks and manuals, scientific projects, etc.); c) scientifically protect linguistic identity of the Serbian language in relation to the political identity of its variants; g) ensure the uniqueness of the Serbian cultural and linguistic space, and d) re-establish the foundational settings of the Serbian philological program as the necessary operating guidelines for the Serbian philological science and Serbian politics within the harmonized „performance" of linguists and politicians in the implementation of a scientifically based and nationally pro-active Serbian language policy.

Keywords: Serbian language, Cyrillic alphabet, Serbian language variants, anglicization, language policy. 